\title{
The Effectiveness of Public Investment in Basic Education in Brazil
}

\section{Eficácia do investimento público na Educação Básica no Brasil}

\author{
JOYSI MORAES \\ BRUNO FRANCISCO BATISTA DIAS \\ SANDRA R. H. MARIANO \\ Universidade Federal Fluminense (UFF)
}

\section{Abstract}

The analysis of educational systems involves four central dimensions: economic, pedagogical, political and cultural. This paper focuses on the economic perspective, which has gained strength with the creation of the Basic Education Development Index (Ideb), and facilitates comparative analyzes of the performance of Brazilian educational systems. This research uses a linear least squares regression in which the dependent variables were the Ideb scores of Brazilian states and the independent variables were the corresponding investments in the maintenance and development of education (MDE), in the period 2005-2015. The results allow a comparative picture to be drawn of the effectiveness of the use of state resources invested by the states. It is verified that the investments in basic education in the states only partially explain the improved learning rates measured by the Ideb. Three distinct situations were observed. In 23 states there was an increase in investment in education accompanied by improvement in the Ideb. In 18 states, the increase in investments accompanied the improvement in the Ideb over a certain period, although this effect was not sustained throughout the historical series. In only 05 states, the relationship between investment and improvement in the Ideb remained positive throughout the analyzed period. Keywords: Public investment. Basic education. Basic Education Development Index 


\section{RESUMO}

A análise dos sistemas educacionais envolve quatro dimensões centrais: econômica, pedagógica, política e cultural. Neste artigo, aborda-se a perspectiva econômica da educação, que ganhou força com a criação do Índice de Desenvolvimento da Educação Básica (Ideb), permitindo análises comparativas do desempenho dos sistemas educacionais brasileiros. Esta pesquisa apresenta um modelo linear, definido pela equação de uma reta ajustada pelo método dos mínimos quadrados, relacionando-se os indicadores do Ideb por estado com o investimento em manutenção e desenvolvimento do ensino (MDE), no período 2005-2015. Os resultados permitiram traçar um quadro comparativo da eficácia do uso dos recursos públicos investidos pelos estados. Verificou-se que os investimentos em educação básica nos estados explicam apenas parcialmente a melhoria dos índices de aprendizagem mensurados pelo Ideb. Observou-se três situações distintas. Em 23 estados houve incremento do investimento em educação acompanhado da melhoria no Ideb. Em 18 estados, o incremento dos investimentos acompanhou a melhoria do Ideb durante certo período, efeito não sustentado ao longo da série histórica. Em apenas 05 estados, a relação entre investimento e melhoria do Ideb se manteve positiva durante todo período analisado.

Palavras-chave: Investimento Público. Educação básica. Índice de Desenvolvimento da Educação Básica.

\section{INTRODUCTION}

The term "quality of education" within the framework of educational systems admits a variety of interpretations (economic, pedagogical, political, social, cultural) depending on the conception of what those systems are expected to provide society (DAVOK, 2007; PAWLOWSKI, 2007; ADELSBERGER et al., 2008; VIEBRANTZ; MOROSINI, 2009), In this paper, we present the results obtained in the literature (MARTINS et al., 2008). Thus, according to Sander (1982, 1995), analyzing the possible outcomes of educational systems implies understanding and taking into account that the education system itself, as well as each school, is composed of at least four analytical dimensions, namely the: economic, pedagogical, political and cultural. 
In the present study, we focus on the economic dimension, which has been little explored in the Brazilian context, but which began to gain space and strength with the creation of the Index of Development of Basic Education in 2005. Since then, it has become feasible to analyze, including comparatively, the performance of each state, public or private network, as well as each school, based on the goals for educational quality defined by the federal government for Brazil's educational systems.

That said, it is pointed out that, in an approach that considers the economic perspective, in the Economics of Education, the quality of education can be ascertained through the efficiency and effectiveness of the educational sector, and, in most cases, of the educational systems and their institutions (DEMO, 1985, 2001; SANDER, 1982, 1995; SCRIVEN, 1991; SAVIANI, 2001; DAVOK, 2007).

The concepts of efficiency and effectiveness, from the perspective of economic rationality, preside over the various organizational and administrative activities in education, such as budget preparation and execution. Thus, education management will be efficient to the extent that it is able to maximize the application of financial resources in the educational system, that is, in its schools (COLEMAN et al., 1966; HANUSHEK, 1986, 1994; WÖßMANN, 2000, 2001, 2003; FIGLIO, 1999, 2004; MENDONÇA NETO; VIEIRA; ANTUNES, 2018). In other words, efficiency is the economic criterion that reveals the administrative capacity to produce the maximum results with the minimum of resources, energy and time. Effectiveness, in turn, is the institutional criterion that reveals the administrative capacity to achieve the goals set or the results proposed (SANDER, 1995).

Therefore, the defining criteria of the economic dimension are the efficiency and effectiveness in the use of available resources, while the analysis seeks to reveal the results obtained in the public education networks in relation to the investments made per student in each network. (HANUSHEK, 2005, 2012, 2013, 2016, HANUSHEK, WÖßMANN, 2007, 2010, 2012). Based on this perspective, it is proposed to ascertain the relationship between investment per student in the Brazilian public network and the result of the performance of those students in the national quality of education assessments tests. 
Thus, in this article, we seek to analyze the correlation between educational investment per student in elementary school (initial and final years), considering the period from 2005 to 2015, that is, from the beginning of the historical series to the last evaluation, published in 2016, and student achievement scores obtained in the national assessments of state education networks.

The Basic Education Development Index (Ideb) of each state was adopted as an indicator of student performance, considering the national scope of the indicator. The Ideb includes a flow indicator and a learning indicator, which combined reflect the quality of the offered education.

The investment per student in elementary schooling (initial and final years) was obtained from the database provided by the Public Educational Budgets Information System on (Sistema de Informações sobre Orçamentos Públicos em Educação (SIOPE)), developed by the Federal Government, through the National Education Development Fund (Fundo Nacional de Desenvolvimento da Educação (FNDE)) in order to collect, process, disseminate and make public information regarding the educational budgets of the states, the Federal District and the municipalities. Despite the imperfections of this database, as pointed out by Araújo (2012) and Davies (2013a, 2013b), such as the sub-declaration of municipal expenditures on early childhood education and youth and adult education, due, in part, to the failure of municipalities and states to provide complete information, among others, this is the main national base on the application of revenue linked to education, and is therefore adopted in this research.

Considering the limited data available, the findings presented herein are an initial effort to correlate the results of investment in education and student performance, which enables the identification of trends and situations, in an exercise designed to contribute towards the discussion from the perspective of the organizational constructs, especially those related to the efficiency and effectiveness of the use of public resources.

\section{ECONOMY OF EDUCATION}

In the mid-1960s, in the context of the civil rights struggles, the US Congress published the Equality of Educational Opportunity 
(COLEMAN et al., 1966), better known as the Coleman Report, which became a reference for studies of education and for the construction of public education policies. This report placed the issue of public investment in education, particularly regarding the efficient use of resources, at the heart of the debate.

Since the publication of that report, which was the first research to relate quality of education to students' learning outcomes, one reason which it became a reference for studies regarding the effectiveness of schools, various studies into education have sought to identify the factors responsible for student performance.

It is a fact that the results presented by Coleman et al. (1966) generated much controversy, since they questioned the continuous and growing demand for more financial resources as if these and these alone explained the results of schools and, therefore, student performance in terms of learning. The Coleman Report, the result of a survey conducted among some 600,000 students, points out that it is not merely by allocating more financial resources in schools that students will learn more or improve their performance. According to Coleman et al. (1966), there is greater intra-school than inter-school variance, that is, there is a greater difference in learning outcomes among students in the same school than among students in different schools. In that case, variations in the quality of each school, individually, would not influence the success of their respective students.

According to the Coleman Report (1966), schools are unable to compensate for social inequalities, and in fact reproduce the inequalities found in society at the time in its results. One of the reasons found at the time for the skepticism regarding the capacity of the school was the preponderance of the factors related to the student's context, therefore, due to the socioeconomic situation of the student, in his school performance (WIECZOREK, 2017; GUEDES; BAQUEIRO; LORDÊLLO, 2015, ADROGUE, 2013). In these terms, schooling would have only a limited effect on learning, either because hereditary or contextual factors were considered predominant, or because the school could not compete with the decisive influence of family background in early childhood, or because environmental factors were unfavorable (COLEMAN et al., 1966; PLOWDEN, 1967; CHILAND, 1971; JENCKS, 1972). 
An important scholar who continued this line of research, but focused, more specifically, on directly relating investments in education and results of student performance, was Eric Hanushek. He sought evidence that the investments made by the governments of at least 50 countries would result in an improvement in the quality of the schools, which would, possibly, result in exceptional rewards for society, reflected in the economic growth of those countries. However, Hanushek (1986, 1989, 1994, 2005, 2007, 2013, 2016) noted that the public resources earmarked for that sector have often been spent inadequately and unproductively, that is, they have not contributed towards improving student performance. Thus, for Hanushek, Rivkin, Taylor (1996) and Hanushek and Wößmann $(2007,2010)$ it is necessary to devote more attention to the use of resources than to the amount invested, given that each school has the minimum necessary.

According to Hanushek and Wößmann (2007, p. 14), “unfortunately, simple and sophisticated analyzes yield the same answer: mere resource investment policies that adopt the already existing structure of school operations are not sufficient to lead to necessary improvements in learning". Likewise, they emphasize that although the resources allocated to schools cannot be considered the only factor that impact on performance, they are fundamental. Parents, individual skills, and friends undoubtedly contribute to achieving or not achieving an adequate performance. However, schools have a special place in the debate because they are most directly affected by public policies (HANUSHEK; WÖßMANN, 2012).

Wößmann (2000), based on research carried out among more than 260,000 students from 39 countries (North America, Western and Eastern Europe and Asia and Israel), pointed out that the problem of the poor quality of public schools was related to the structure of the educational system, not just the lack of resources. According to the author, the international differences observed in student performance were not caused by differences in educational resources, but mainly due to institutional differences in educational systems. According to Wößmann's (2000) research, systems that, among other things, prioritize school autonomy, stimulate competition between schools, allow teachers to select which teaching 
methods they believe to be most effective and encourage parent participation in the students' school lives perform better than more rigid educational systems.

The researchers do not deny that investments are productive, since their studies point out that some minimal levels of resources are necessary and valuable in promoting student learning. However, they point out that they found no consistent or systematic relationships between student performance and variables such as teacher salaries, years of study and/or teacher experience, teacher/student ratios, and expenditure per student (HANUSHEK, 2005, 2012).

As Nascimento (2007) notes, "the influence of this current extends to those who, in their analysis, initially tend to contest it, but then end up endorsing it. This is the case of David Figlio (1999, 2004), who attributes, in part, the largely insignificant results found by the mainstream to the restrictive functional forms used by them". Despite which, David Figlio himself, in Figlio and Kenny (2007, 2009), acknowledges that in fact there is very little evidence that can be used to emphatically argue that greater investment in education is reflected in better school performance.

But if, on the one hand, the mainstream, based on econometric studies, presents evidence that factors such as higher expenditure on education, better teacher salaries, and reduced numbers of students per class, among others are statistically insignificant vis-a-vis student performance, the counterpoint to this line of thought is led by Hedges, Laine, and Greenwald (1994, 1996a, 1996b). Those researchers reanalyzed the data collected by researchers belonging to the previous current and reviewed them using more sophisticated methods of synthesis. What they observed were positive systematic relationships between resources and school outcomes. Moreover, analyzes of the magnitude of those relationships suggest that the median (regression coefficient) ratio is sufficient to have practical significance. Although in their reanalysis, they suggest that the data do not support the conclusions reached by Hanushek and others who followed, Hedges, Laine and Greenwald (1994, 1996a, 1996b) emphasize that caution is needed in the use of the data set, especially if they are used for the elaboration of public policies. 
Card and Krueger (1996), Haurin and Brasington (1996), (Kim, 2001), Deke (2003), Brasington and Haurin (2009), Baker (2016) and other researchers who have sought to carry out the same type of research in different countries believe the results presented by studies that shift the focus of curriculum performance tests onto the effects of school resources on education outcomes should be cautious. For those researchers, school performance or achievement tests alone as a measure of student performance are insufficient to measure learning. Performance assessment tests should be replaced by long-term results, absenteeism rates and the salary levels of ex-students.

Finally, as Nascimento $(2007,2008)$ points out, there are few studies that seek to identify whether or not there is a correlation between investments in education and student performance in Latin American countries. In Brazil, for example, although the Basic Education Development Index (Ideb) is already part of the reality of school managers and public school networks, mainly because it represented a significant change in the way education was monitored in the country, there is still considerable resistance to the use of these indicators (ALVES; SOARES, 2007; FERNANDES; GREMAUD, 2009; RIBEIRO; GUSMÃO, 2010, 2013; BROOKE; SOARES, 2008; BROOKE; CUNHA, 2011; TAVARES JÚNIOR; NEUBERT, 2014; WERLE; KOETZ; MARTINS, 2015).

\section{Methodological PRocedures}

In this study, the analysis was performed using the linear regression statistical method. This method is a powerful tool used to identify the correlation between dependent and independent variables by constructing a linear model defined by the equation of a straight line fitted by the least squares method (HAIR et al., 1998).

The purpose of the linear regression test in this study was to identify the capacity of investment per student in the Maintenance and Development of Education (MDE) modality to influence the average performance of the Basic Education Development Index (Ideb) in the initial and final years of teaching in state networks over the period from 2005 to 2015. Figure 1 illustrates the investigated relationship: 
Figure 1- Relationship to be investigated among the variables.

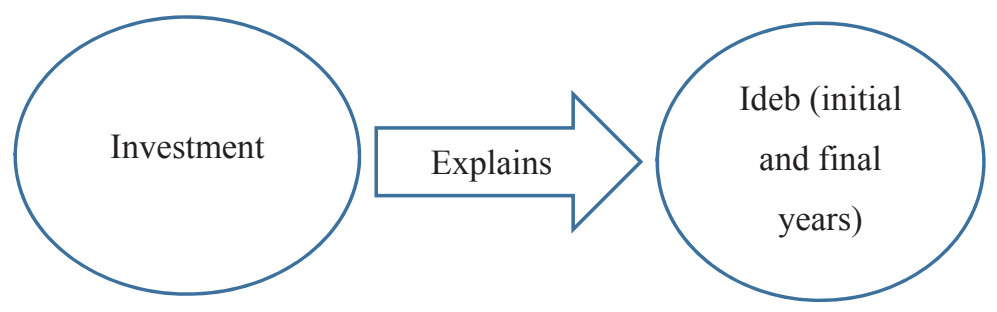

Source: Developed by the authors.

The dependent variable is the Ideb performance that takes values on a continuous scale from zero to ten. The Ideb indicator, created in 2007 by the National Institute of Educational Studies and Research (INEP), synthesizes two concepts related to the quality of education: exam pass rates and average performance of students in Portuguese and mathematics. They were calculated based on the data on school pass rates obtained in the School Census, and performance averages in the Inep, Saeb and Prova Brasil assessments. As stated by Inep (2011, p.1):

The historical series of Ideb results began in 2005, from which biennial quality targets were set to be reached not only by the country, but also by schools, municipalities and units of the Federation. The aim is that each instance evolves in order to contribute, together, so that Brazil reaches the average educational level of the OECD countries. In numerical terms, this means progressing from the national average 3.8 , registered in 2005, in the first phase of elementary school, to an Ideb of 6.0 in 2022, the year of the Independence bicentennial.

The value defined for Ideb used in the statistical test was adjusted to include both first and final years of elementary school. To do so, the calculation was performed, as shown in figure 2, in order to include the values reached in the indicator by the Brazilian states for the two modalities of elementary school: 
Figure 2 - Calculation of the Ideb average for the first and final years of elementary school.

$$
I d e b=\frac{I D E B_{\text {Initial years }}+I D E B_{\text {Final years }}}{2}
$$

Source: Elaborated by the authors.

The independent variable 'educational investment per student' takes continuous values calculated according to the two-year average of resources (in Brazilian currency, Reals) applied to the Maintenance and Development of Education (MDE). All the amounts were monetarily corrected according to the official inflation rate in Brazil (IPCA) for $12 / 31 / 2015$. As the independent variable (Ideb) is a biannual indicator and the data available for the dependent variable (investments) are annual, it was adjusted accordingly. Hence the use of the average value, so that correlated investments contemplate the historical period in relation to the indicator of performance. Figure 3 describes the adjustment made:

Figure 3 - Calculation of the average investments in the biennium of the Ideb.

\begin{tabular}{|l|}
$\qquad G m a_{e a}=\frac{G a_{e a}+G a_{e(a-1)}}{2}$ \\
\hline$G a_{e}=\frac{\text { Investiments in MDE in elementary education }}{\text { Total number of pupils enrolled in elementary schools }}$ \\
$\mathrm{i}=$ Accumulated inflation in the period
\end{tabular}

Source: Prepared by the authors.

The resources applied to the Maintenance and Development of Education (MDE) finance basic education, contemplating a set of actions described in Figure 4 . 


\section{Figure 4 - Composition of the items financed in the Maintenance and Development of Education (MDE) category.}

Fundable Activities

I - Remuneration and training of teaching staff and other education professionals; By remuneration we should understand the total payments (salary, social charges and gratuities such as: time of service, titling, among others, provided for in the law of positions and salaries) due to members of the teaching staff employed at the State, Federal District or Municipality levels.

II - Acquisition, maintenance, construction and conservation of facilities and equipment necessary for teaching;

III - Use and maintenance of goods and services linked to education;

IV - Statistical surveys, studies and research aimed at the improving the quality of and expanding education;

V - Performance of activities - means necessary for the functioning of education systems;

VI - Granting scholarships to students from public and private schools;

VII - Amortization and financing of credit operations intended to comply with the provisions of this article;

VIII - Acquisition of school didactic material and maintenance of school transportation programs.

Source: Brasil (1996)

Among its characteristics, we highlight the reliability and the broad degree of isonomy and comparability between the information presented by all the entities within the federation that feed the system, whose access is restricted to the declarant. The opening of exceptions, even if accompanied by formal and specific justifications, creates precedents that disqualify the standardization and comparability of existing information in the system, and are contrary to the legal provisions on which the system is based. The SIOPE is annual and there is a deadline for the transmission of data, compliance with which is a sine qua non for the voluntary transfers from the Federal Government. As established in Art.3 of the Ordinance of the MEC, n.844, of July 8, 2008 (DOC.I), Art. As of January 1, 2009, the full and updated SIOPE completion by the States, Federal District and 
Municipalities became a condition for the signing of agreements and terms of cooperation with the Ministry of Education or administrative bodies indirectly linked to it.

In view of the above, the relationship to be estimated by the linear regression test correlated these variables and the values assumed by them as shown in Table 1:

Table 1 - Correlated variables.

\begin{tabular}{|l|l|l|l|l|l|l|l|l|l|l|l|}
\hline $\begin{array}{l}\text { Year of the } \\
\text { indicator }\end{array}$ & 2005 & 2006 & 2007 & 2008 & 2009 & 2010 & 2011 & 2012 & 2013 & 2014 & 2015 \\
\hline Ideb- variable & Ideb5 & & Ideb7 & & Ideb9 & & Ideb11 & & Ideb13 & & Ideb15 \\
\hline $\begin{array}{l}\text { Investment } \\
\text { (Siope) - va- } \\
\text { riable }\end{array}$ & Inv-05* & $\begin{array}{l}\text { Inv- } \\
6-7\end{array}$ & & Inv-8-9 & & $\begin{array}{l}\text { Inv- } \\
10- \\
11\end{array}$ & & $\begin{array}{l}\text { Inv-12- } \\
13\end{array}$ & & $\begin{array}{l}\text { Inv- } \\
14-15\end{array}$ & \\
\hline
\end{tabular}

* In view of the lack of information for the year 2004, for 2005, only the amount invested per student in that year was used.

Source: Prepared by the authors.

This relation to be investigated and described in Table 04 is modeled using the linear equation contained in figure 5.

Figure 5 - Equation to be estimated by the linear regression test.

\begin{tabular}{|l|}
$\qquad \alpha_{e a}+\beta_{e} G a_{e a}+\epsilon_{e a}=I D E B_{e a}$ \\
\hline For: $-\infty \leq \alpha \leq+\infty, \forall-\infty \leq \beta \leq+\infty$ \\
Where: \\
$I D E B_{e a}=$ Performance $\frac{\text { level }}{\text { score }}$ obtained by the state in the IDEB in the period a; \\
$\alpha_{\text {en }}=$ Constant that represents the interception of the straight line with the vertical axis \\
$\beta_{e}=$ expresses the sensitivity of the performance of the IDEB to the variable Ga \\
Ga $=$ average expenditure per pupil by the state "e" for the year a e (a-1) \\
$\epsilon_{\text {en }}$ \\
$=$ Term representing disruption of the model, includes all the residual factors and possible measu \\
\hline
\end{tabular}

Source: Elaborated by the authors.

The statistical test to obtain the values of the coefficients that determine the model to be estimated was performed with the aid of the Statistical Package for Social Science (SPSS) software. 


\section{RESULTS AND DISCUSSION}

As shown above, the model resulting from the statistical test was built by correlating the Ideb data (table 2) with the investments made in MDE over the period (table 3).

Table 2 - Ideb by state in elementary schooling (first and final years).

\begin{tabular}{|c|c|c|c|c|c|c|}
\hline State & 2005 & 2007 & 2009 & 2011 & 2013 & 2015 \\
\hline Acre & 3.4 & 3.8 & 4.3 & 4.45 & 4.8 & 4.95 \\
\hline Alagoas & 2.7 & 3.0 & 3.0 & 2.95 & 3.2 & 3.6 \\
\hline Amapá & 3.3 & 3.2 & 3.6 & 3.7 & 3.6 & 3.95 \\
\hline Amazonas & 3.0 & 3.6 & 4.05 & 4.35 & 4.5 & 4.95 \\
\hline Bahia & 2.6 & 2.65 & 3.0 & 3.35 & 3.55 & 3.75 \\
\hline Ceará & 3.0 & 3.45 & 3.9 & 4.05 & 4.45 & 5.0 \\
\hline Distrito Federal & 3.85 & 4.15 & 4.65 & 4.65 & 4.7 & 4.8 \\
\hline Espírito Santo & 3.6 & 3.85 & 4.4 & 4.35 & 4.65 & 4.75 \\
\hline Goiás & 3.6 & 3.85 & 4.25 & 4.65 & 5.25 & 5.4 \\
\hline Maranhão & 3.2 & 3.35 & 3.8 & 3.8 & 4.0 & 4.05 \\
\hline Mato Grosso & 3.25 & 4.0 & 4.55 & 4.7 & 4.65 & 5.05 \\
\hline Mato Grosso do Sul & 3.05 & 3.75 & 4.0 & 4.2 & 4.4 & 4.75 \\
\hline Minas Gerais & 4.25 & 4.3 & 4.95 & 5.2 & 5.45 & 5.4 \\
\hline Pará & 2.95 & 2.85 & 3.4 & 3.55 & 3.3 & 3.7 \\
\hline Paraíba & 2.75 & 3.15 & 3.25 & 3.45 & 3.6 & 3.85 \\
\hline Paraná & 4.15 & 4.6 & 4.65 & 4.6 & 5.15 & 5.25 \\
\hline Pernambuco & 2.75 & 3.0 & 3.45 & 3.75 & 3.95 & 4.4 \\
\hline Piauí & 2.6 & 3.15 & 3.6 & 3.85 & 4.0 & 4.2 \\
\hline Rio de Janeiro & 3.3 & 3.35 & 3.55 & 3.75 & 4.15 & 4.4 \\
\hline Rio Grande do Norte & 2.6 & 2.85 & 3.2 & 3.3 & 3.5 & 3.85 \\
\hline Rio Grande do Sul & 3.85 & 4.1 & 4.3 & 4.45 & 4.7 & 4.75 \\
\hline Rondônia & 3.4 & 3.65 & 3.9 & 4.1 & 4.55 & 4.85 \\
\hline Roraima & 3.35 & 3.5 & 3.95 & 4.05 & 4.15 & 4.4 \\
\hline Santa Catarina & 4.2 & 4.4 & 4.6 & 5.2 & 4.9 & 5.3 \\
\hline São Paulo & 4.15 & 4.35 & 4.85 & 4.85 & 5.05 & 5.55 \\
\hline Sergipe & 2.95 & 3.15 & 3.2 & 3.4 & 3.4 & 3.6 \\
\hline Tocantins & 3.5 & 3.9 & 4.2 & 4.4 & 4.4 & 4.4 \\
\hline
\end{tabular}

Source: Inep (2016) 
Table 3 - Average investment per student by state in elementary schooling (first and final years), by the Inpc.

\begin{tabular}{|c|c|c|c|c|c|c|}
\hline STATE & $2005^{* *}$ & 2006 and 2007 & 2008 and 2009 & 2010 and 2011 & 2012 and 2013 & 2014 and 2015 \\
\hline Acre & $\mathrm{R} \$ 6,343.82$ & $\mathrm{R} \$ 5,448.13$ & $\mathrm{R} \$ 7,712.80$ & $\mathrm{R} \$ 6,605.87$ & $\mathrm{R} \$ 7,884.89$ & $\mathrm{R} \$ 6,797.51$ \\
\hline Alagoas & $\mathrm{R} \$ 1,314.81$ & $\mathrm{R} \$ 1,417.20$ & $\mathrm{R} \$ 5,766.46$ & $\mathrm{R} \$ 6,771.66$ & $\mathrm{R} \$ 8,522.57$ & * \\
\hline Amapá & $\mathrm{R} \$ 2,963.55$ & $\mathrm{R} \$ 2,755.17$ & $\mathrm{R} \$ 6,970.81$ & $\mathrm{R} \$ 7,533.98$ & $\mathrm{R} \$ 10,100.89$ & $\mathrm{R} \$ 9,118.46$ \\
\hline Amazonas & $\mathrm{R} \$ 2,515.47$ & $\mathrm{R} \$ 2,083.54$ & $\mathrm{R} \$ 3,610.00$ & $\mathrm{R} \$ 3,126.59$ & $\mathrm{R} \$ 5,702.42$ & $\mathrm{R} \$ 6,256.73$ \\
\hline Bahia & $\mathrm{R} \$ 2,580.52$ & $\mathrm{R} \$ 2,032.59$ & $\mathrm{R} \$ 4,165.15$ & $\mathrm{R} \$ 3,666.59$ & $\mathrm{R} \$ 4,681.28$ & $\mathrm{R} \$ 5,036.94$ \\
\hline Ceara* $^{*}$ & $\mathrm{R} \$ 5,114.08$ & $\mathrm{R} \$ 5,649.30$ & $\mathrm{R} \$ 8,996.41$ & $\mathrm{R} \$ 6,873.06$ & $\mathrm{R} \$ 3,833.82$ & $\mathrm{R} \$ 3,385.70$ \\
\hline Distrito federal & $\mathrm{R} \$ 4,596.67$ & $\mathrm{R} \$ 4,296.81$ & $\mathrm{R} \$ 7,768.74$ & $\mathrm{R} \$ 9,078.46$ & $\mathrm{R} \$ 9,279.12$ & $\mathrm{R} \$ 9,864.10$ \\
\hline Espírito santo & $\mathrm{R} \$ 3,807.68$ & $\mathrm{R} \$ 3,062.71$ & $\mathrm{R} \$ 3,293.17$ & $\mathrm{R} \$ 6,672.50$ & $\mathrm{R} \$ 8,543.41$ & $\mathrm{R} \$ 8,404.32$ \\
\hline Goiás & $\mathrm{R} \$ 3,288.29$ & $\mathrm{R} \$ 3,237.20$ & $\mathrm{R} \$ 3,974.88$ & $\mathrm{R} \$ 6,080.55$ & $\mathrm{R} \$ 7,277.38$ & $\mathrm{R} \$ 7,946.82$ \\
\hline Maranhão & $\mathrm{R} \$ 1,929.41$ & $\mathrm{R} \$ 2,029.23$ & $\mathrm{R} \$ 6,678.36$ & $\mathrm{R} \$ 4,396.49$ & $\mathrm{R} \$ 8,501.34$ & $\mathrm{R} \$ 8,162.27$ \\
\hline Mato grosso & $\mathrm{R} \$ 3,140.19$ & $\mathrm{R} \$ 2,620.86$ & $\mathrm{R} \$ 6,049.30$ & $\mathrm{R} \$ 6,830.92$ & $\mathrm{R} \$ 6,351.76$ & $\mathrm{R} \$ 6,127.41$ \\
\hline $\begin{array}{l}\text { Mato grosso do } \\
\text { Sul }\end{array}$ & $\mathrm{R} \$ 5,479.30$ & $\mathrm{R} \$ 4,047.35$ & $\mathrm{R} \$ 7,372.15$ & $\mathrm{R} \$ 8,098.49$ & $\mathrm{R} \$ 7,383.87$ & $\mathrm{R} \$ 4,084.06$ \\
\hline Minas gerais & $\mathrm{R} \$ 2,247.92$ & $\mathrm{R} \$ 2,657.88$ & $\mathrm{R} \$ 5,288.04$ & $\mathrm{R} \$ 5,838.73$ & $\mathrm{R} \$ 7,207.48$ & * \\
\hline Para & $\mathrm{R} \$ 1,614.35$ & $\mathrm{R} \$ 1,498.34$ & $\mathrm{R} \$ 3,630.09$ & $\mathrm{R} \$ 5,340.83$ & $\mathrm{R} \$ 5,401.83$ & $\mathrm{R} \$ 5,134.18$ \\
\hline Paraíba & $\mathrm{R} \$ 2,052.03$ & $\mathrm{R} \$ 1,573.17$ & $\mathrm{R} \$ 3,571.45$ & $\mathrm{R} \$ 4,763.08$ & $\mathrm{R} \$ 4,627.27$ & $\mathrm{R} \$ 5,941.34$ \\
\hline Paraná & $\mathrm{R} \$ 2,334.75$ & $\mathrm{R} \$ 2,303.38$ & $\mathrm{R} \$ 3,658.70$ & $\mathrm{R} \$ 4,331.87$ & $\mathrm{R} \$ 6,544.78$ & $\mathrm{R} \$ 7,063.97$ \\
\hline Pernambuco & $\mathrm{R} \$ 1,983.69$ & $\mathrm{R} \$ 2,187.11$ & $\mathrm{R} \$ 5,499.35$ & $\mathrm{R} \$ 7,591.35$ & $\mathrm{R} \$ 9,739.09$ & $\mathrm{R} \$ 10,697.79$ \\
\hline Piauí & $\mathrm{R} \$ 2,776.78$ & $\mathrm{R} \$ 2,885.17$ & $\mathrm{R} \$ 4,144.84$ & $\mathrm{R} \$ 5,217.13$ & $\mathrm{R} \$ 4,015.51$ & $\mathrm{R} \$ 1,588.09$ \\
\hline Rio de janeiro & $\mathrm{R} \$ 3,337.26$ & $\mathrm{R} \$ 7,807.07$ & $\mathrm{R} \$ 9,491.80$ & $\mathrm{R} \$ 8,365.02$ & $\mathrm{R} \$ 5,364.62$ & $\mathrm{R} \$ 6,327.99$ \\
\hline $\begin{array}{l}\text { Rio grande do } \\
\text { Norte }\end{array}$ & $\mathrm{R} \$ 2,642.68$ & $\mathrm{R} \$ 1,738.09$ & $\mathrm{R} \$ 4,750.72$ & $\mathrm{R} \$ 4,106.33$ & $\mathrm{R} \$ 5,127.99$ & * \\
\hline Rio grande do Sul & $\mathrm{R} \$ 2,672.31$ & $\mathrm{R} \$ 1,962.75$ & $\mathrm{R} \$ 3,524.78$ & $\mathrm{R} \$ 5,181.96$ & * & $*$ \\
\hline Rondônia & $\mathrm{R} \$ 2,363.55$ & $\mathrm{R} \$ 2,249.27$ & $\mathrm{R} \$ 5,264.77$ & $\mathrm{R} \$ 5,931.40$ & $\mathrm{R} \$ 5,700.91$ & $\mathrm{R} \$ 5,406.24$ \\
\hline Roraima & $\mathrm{R} \$ 4,010.64$ & $\mathrm{R} \$ 4,737.35$ & $\mathrm{R} \$ 8,440.08$ & $\mathrm{R} \$ 7,415.05$ & $\mathrm{R} \$ 9,415.14$ & $\mathrm{R} \$ 8,221.59$ \\
\hline Santa Catarina & $\mathrm{R} \$ 3,300.89$ & $\mathrm{R} \$ 2,289.35$ & $\mathrm{R} \$ 4,330.89$ & $\mathrm{R} \$ 4,573.32$ & $\mathrm{R} \$ 5,350.12$ & $\mathrm{R} \$ 6,005.24$ \\
\hline São Paulo & $\mathrm{R} \$ 3,450.90$ & $\mathrm{R} \$ 3,568.40$ & $\mathrm{R} \$ 5,858.26$ & $\mathrm{R} \$ 5,555.96$ & $\mathrm{R} \$ 4,553.64$ & $\mathrm{R} \$ 6,213.54$ \\
\hline Sergipe & $\mathrm{R} \$ 2,974.96$ & $\mathrm{R} \$ 2,635.14$ & $\mathrm{R} \$ 3,458.31$ & $\mathrm{R} \$ 4,542.59$ & $\mathrm{R} \$ 4,855.29$ & $\mathrm{R} \$ 4,172.53$ \\
\hline Tocantins & $\mathrm{R} \$ 3,432.60$ & $\mathrm{R} \$ 2,458.85$ & $\mathrm{R} \$ 5,667.11$ & $\mathrm{R} \$ 5,792.54$ & $\mathrm{R} \$ 6,444.16$ & $\mathrm{R} \$ 5,929.67$ \\
\hline
\end{tabular}

* Information not available.

** In the absence of information for the year 2004, in the case of 2005, only the amount invested per student in that year was used.

Source: SIOPE (2016). 
After the statistical test, it was possible to estimate the coefficients of the linear regression and construct the complete equation that represents the relation between investment per student and Ideb results for the Brazilian states during the period under analysis. Table 4 contains the coefficients obtained with linear regression:

Table 4 - Regression coefficients.

\begin{tabular}{|c|c|c|c|c|c|c|}
\hline \multirow{2}{*}{\multicolumn{2}{|c|}{$\begin{array}{l}\text { Indicator } \\
\mathrm{B}\end{array}$}} & \multicolumn{2}{|c|}{$\begin{array}{l}\text { Non-standardized } \\
\text { coefficients }\end{array}$} & \multirow[t]{2}{*}{$\begin{array}{l}\text { Standard } \\
\text { Coefficients }\end{array}$} & \multirow[t]{2}{*}{$\mathrm{T}$} & \multirow[t]{2}{*}{ Sig. } \\
\hline & & $\begin{array}{l}\text { Standard } \\
\text { Error }\end{array}$ & Beta & & & \\
\hline \multirow{2}{*}{1} & (Constant) & 3.236 & 0.126 & & 25.984 & 0.000 \\
\hline & Investments & $1.2 \mathrm{E}-5$ & 0.000 & 0.434 & 6.001 & 0.000 \\
\hline
\end{tabular}

Source: Elaborated by the authors.

The non-normalized coefficients, which represent the extent to which the value of the independent variable contributes to the value of the dependent variable, reveal that in relation to the investment per student, for each real invested per student in the year, there was an increase of 0.0012 points on the Ideb. Regarding the value attributed to the constant, it is understood that, if there had been no increase in spending per student over the years, the average Ideb would be 3.236 points per state. The equation that describes this pattern in the relation between the variables is shown in figure 6.

\section{Figure 6 - Equation of the line with the coefficients defined by the regression test.}

$$
0.03236+1,2 \cdot 10^{-5} G a_{e a}=I D E B_{e a}
$$

Source: Elaborated by the authors.

Table 5 shows the capacity of the variation in the investment per student to explain the result obtained by the states in the Ideb. 
Table 5 - Summary of the Model.

\begin{tabular}{|l|l|l|l|}
\hline Model & R & R-squared & Estimated Standard Error \\
\hline 1 & $0.434^{\mathrm{a}}$ & 0.189 & 0.63363 \\
\hline \multicolumn{2}{|l|}{ a. Predictive: (Constant), Investments } \\
\hline
\end{tabular}

Source: Elaborated by the authors

When correlating the variables, the coefficient of determination was found to an R-squared of 0.189 . This value indicates the predictive capacity of the tested model. Accordingly, $18.9 \%$ of the variation in the Ideb can be explained by the variation in the investment per student in the period. And for this association, there is a directly proportional relationship of force between the variables, considering the value assumed by $\mathrm{R}$ is greater than zero. That is, in relation to the performances obtained by the states in the Ideb, $18.9 \%$ is positively related to the variation in the resources invested per student in the period.

Regarding the significance of the model, the values described in table 6, were obtained through the analysis of variance (ANOVA).

Table 6 - Anova Test

\begin{tabular}{|l|l|l|l|l|l|l|}
\hline \multicolumn{2}{|l|}{ Model } & $\begin{array}{l}\text { Sum of the } \\
\text { Squares }\end{array}$ & $\mathrm{df}$ & $\begin{array}{l}\text { Average of } \\
\text { the Squares }\end{array}$ & $\mathrm{F}$ & Sig. \\
\hline \multirow{4}{*}{1} & Regression & 14.457 & 1 & 14.457 & 36.008 & $.000^{\mathrm{b}}$ \\
\cline { 2 - 8 } & Residual & 62.230 & 155 & .401 & & \\
\cline { 2 - 7 } & Total & 76.687 & 156 & & & \\
\hline
\end{tabular}

Source: Elaborated by the authors.

The Anova test resulted in a significance level (sig.) of less than 0.001 . Based on the values obtained from the analysis of variance test, it can be concluded that the model is valid and significant. This is because the value of sig. is approximately zero, which means that for any level of significance. The same can be concluded based on the F statistic, which had a value 36.008. Through this value assig- 
ned to $\mathrm{F}$, the amount of systematic variance in the data with the amount of non-systematic variance shows that the Ideb is sensitive to investments in MDE.

The relationship between the values assumed by the variables and the line generated by the equation described in Table 06 can be visualized in the scatter diagram shown in figure 7.

Figure 7 - Scatter graph of the model

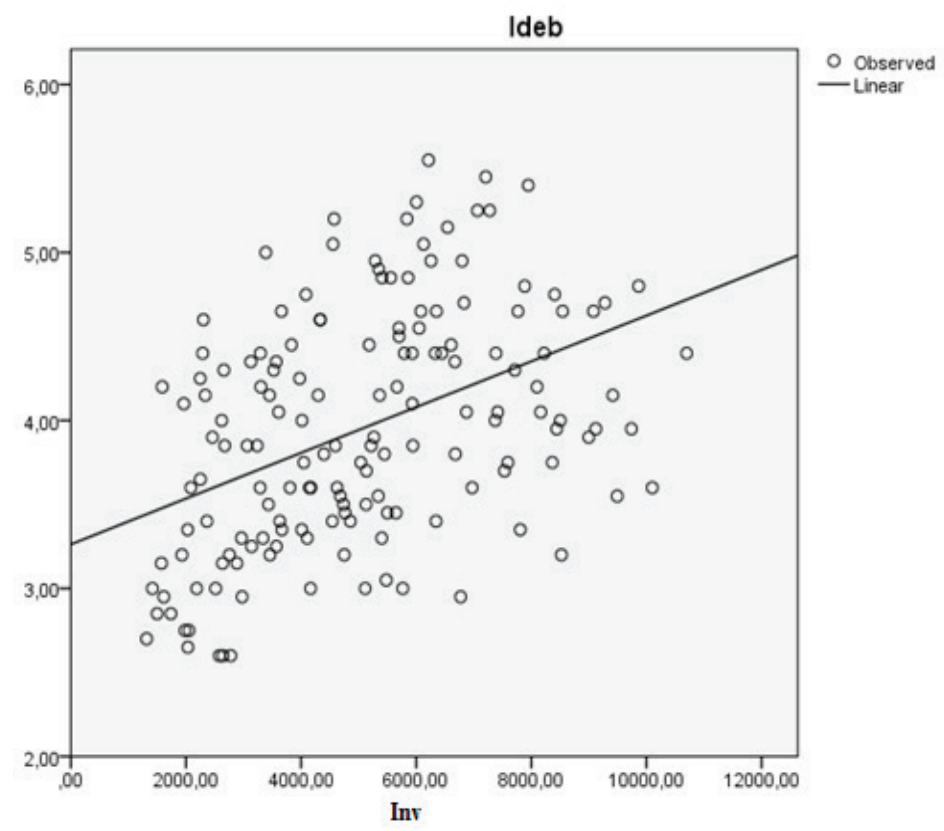

Source: Elaborated by the authors

The scatter diagram described in figure 7 represents the relationship between the two variables contained in the model. The straight line crossing the points consists of the representation, in the Cartesian plane, of the equation contained in figure 6, following linear adjustment using the least squares method. The abscissa axis (Inv), horizontally oriented, contains the scale of values in Reals invested per student. The ordinate axis (Ideb), vertically oriented, is composed of the scale of magnitude of the Ideb. Each point obser- 
ved in the diagram consists of an association of values invested and performance obtained for a given state in one of the years within the studied period.

It is observed that the association between the dependent and independent variables is relatively dispersed, due to the misalignment of the points when compared to the straight line or, even, when observing the distance of a certain point in relation to the straight line. Although the dispersion between the associated values and the model is moderate, there is a positive tendency in the slope values, even for those that are farthest from the trend line. In other words, objectively, the results of the Ideb tend to be greater as the investments increase.

It is noteworthy that most of the points that are concentrated near the line, and which therefore are better explained by the model, lie synthetically in the area of the graph delimited by the Cartesian points $(3.0(2,000.00)$ and $(4.0,6,000.00)$. However, as the values of the Ideb and Inv axes increase, there are fewer points in proximity to the line, and therefore, the model's ability to explain the relation to these more dispersed values is reduced. In other words, it is understood that increases in investment in the range of $R \$ 2,000.00$ to $R \$ 6,000.00$ better explain the evolution of the Ideb in the range of 3.00 to 4.00 points than in relation to other values of expenditure. That means the investments are necessary and can explain the improvement in the learning indices, as measured by the Ideb, up to a certain level. However, from a given point of view, the investment no longer translates into improved learning outcomes, since Ideb results are no longer explained by the increase in investments per student.

Likewise, the performance below 3.00 and above 4.00 in the Ideb are explained less by the investment per student, given the greater distance of these points in relation to the line. Accordingly, in relation to the values that exceed 5.0 on the Ideb scale, there is practically no explanation associated with the investment variable, regardless of the volume. It is also apparent that the highest scale value in relation to the Ideb axis is, precisely, the one with the greatest relative distance in comparison to the line. That is, the highest score ever obtained in the Ideb by a state is not explained by the investment made.

What is seen, therefore, is that the results of the poor performance schools can be explained by the same model proposed by 
Coleman (1966), that is, the socioeconomic characteristics would be the predominant factors influencing performance, and not only the use of the resources made available to schools. This theoretical approximation may even occur due to the very scope of Coleman's research. On the other hand, the average school performance tends to confirm the results reported by Hanushek (2012) and Hedges, Laine and Greenwald (1994, 1996a, 1996b), where there is a closer relationship between the analyzed factors.

Figures 8, 9, 10, 11 and 12show the individual contributions by each Brazilian state in the general model described in Table 06.).

Figure 8 - Scatter graph for the Northern states.
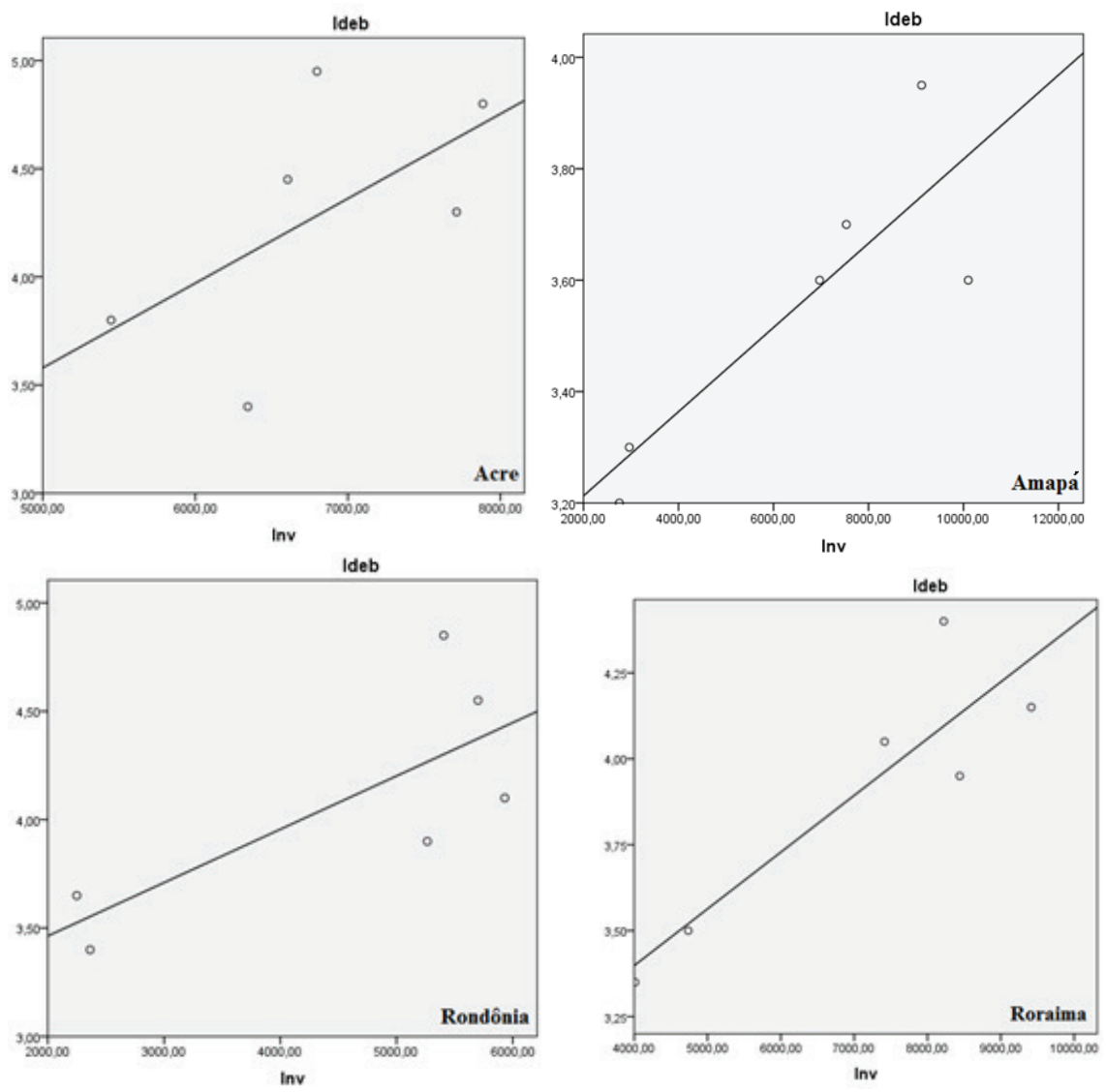


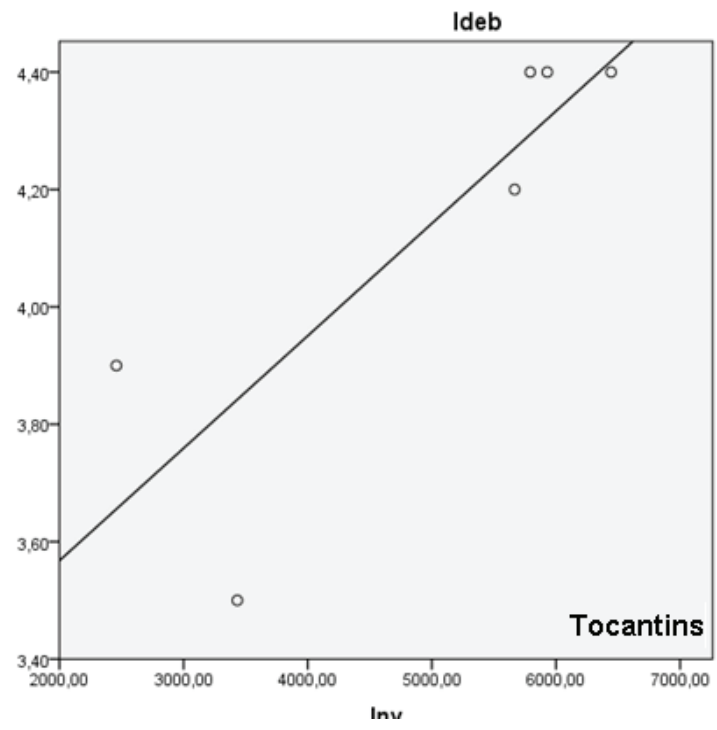

Source: Elaborated by the authors.

In the Northern region, the average expenditure per student in the period grew by $101 \%$, from $\mathrm{R}$ \$ 3,320.57 in 2005 to $\mathrm{R} \$ 6,694.91$ in 2015. On the other hand, the evolution of Ideb was $36.24 \%$, rising from 3.27 to 4.45 points. As for the capacity of the investments to explain the results at the individual level of aggregation of states, based on the R-square factor of each curve, it was high for the state of Roraima (0.804), moderate for Pará (0.777), Amapá (0.73), Tocantins (0.703), Amazonas (0.7), Rondônia (0.588) and low for Acre (0.356). The results suggest that the resources applied and the improvement in Ideb that occurred in the state of Roraima were more closely when compared with the other states in the region.

In the Northeastern region, the expansion of resources per student reached the equivalent of $125 \%$, jumping from $\mathrm{R} \$ 2,596.55$ to $\mathrm{R}$ $\$ 5,848.36$ from 2005 to 2015, while the Ideb average increased from 3.30 to 4.55 , which represents an increase of $44.33 \%$. It is noteworthy that the level of correlation between the variables in the individual curves is almost perfect for the state of Pernambuco (R-square $=$ 0.9636), significantly high for Maranhão (0.895) and Bahia (0.829), moderate for Paraíba $(0,799)$, Rio Grande do Norte $(0,73)$, Sergipe $(0,594)$ and Alagoas $(0,525)$, low for Ceará $(0,147)$ and nonexistent 
for Piauí $(0,015)$. The data suggest that in the Northeast the state of Pernambuco has a better capacity to influence the Ideb results by allocating resources to education.

Figure 9 - Scatter graph for the Northeastern states.
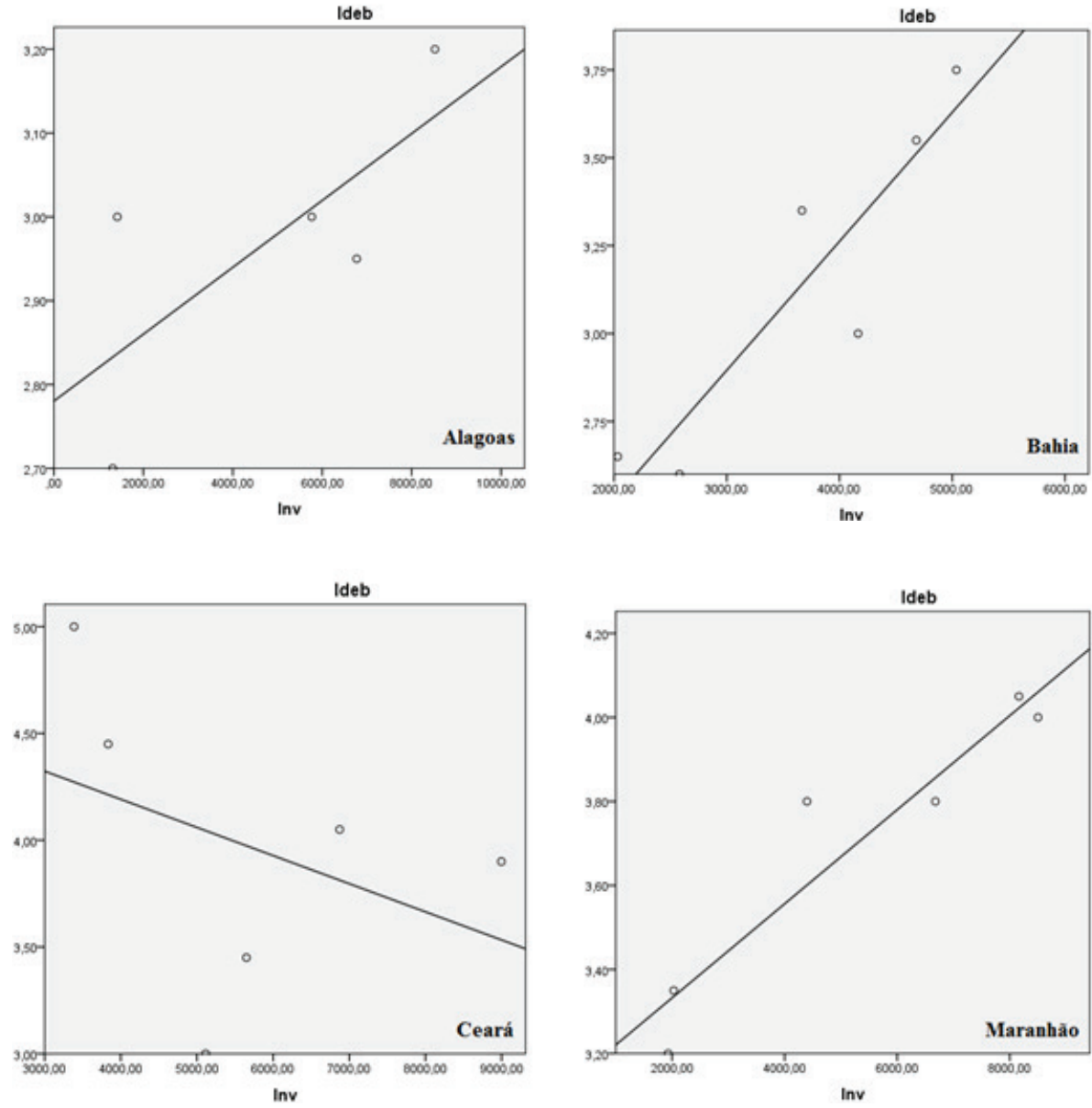

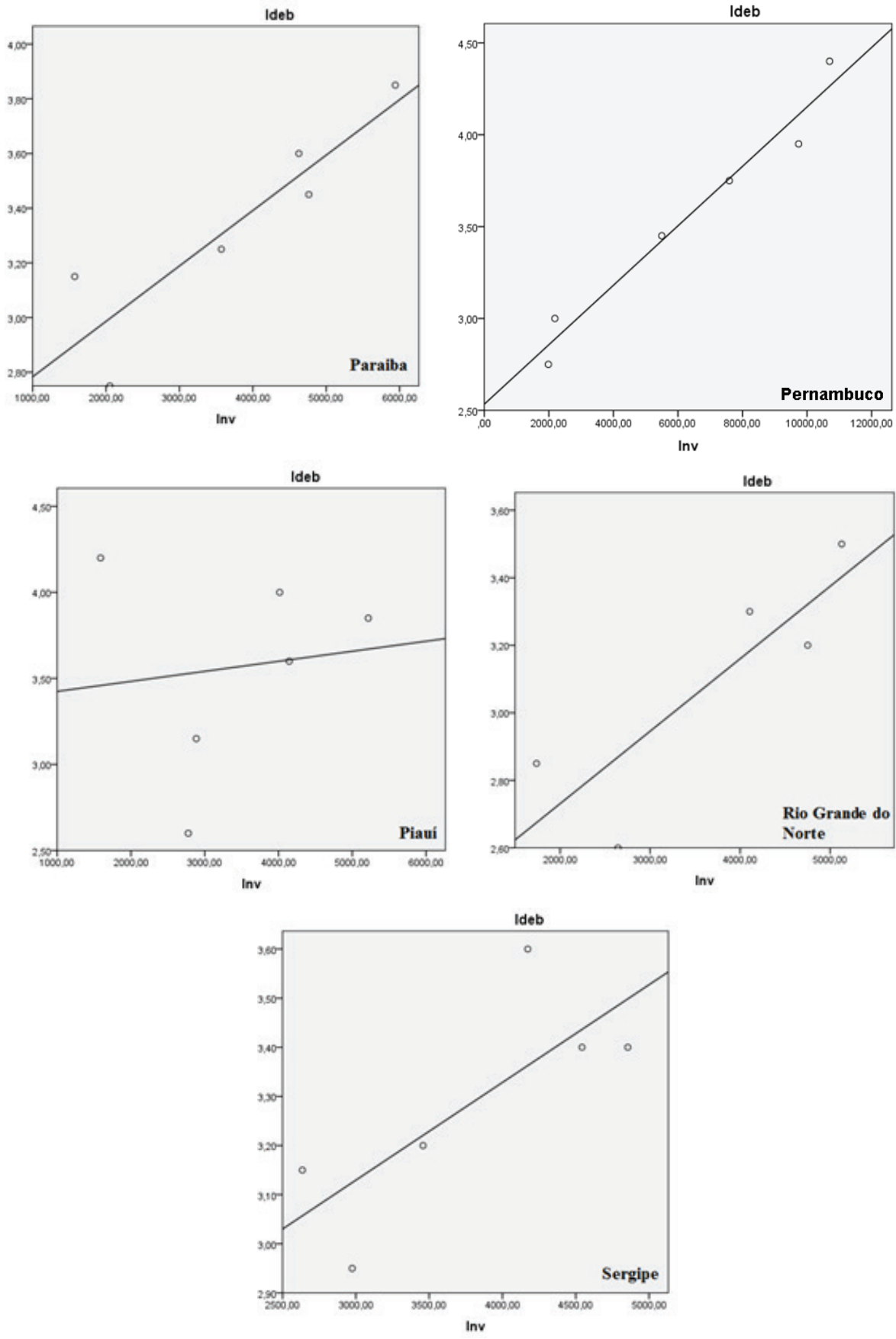

Source: Elaborated by the authors. 
Figure 10 - Scatter graph for the Midwestern states.
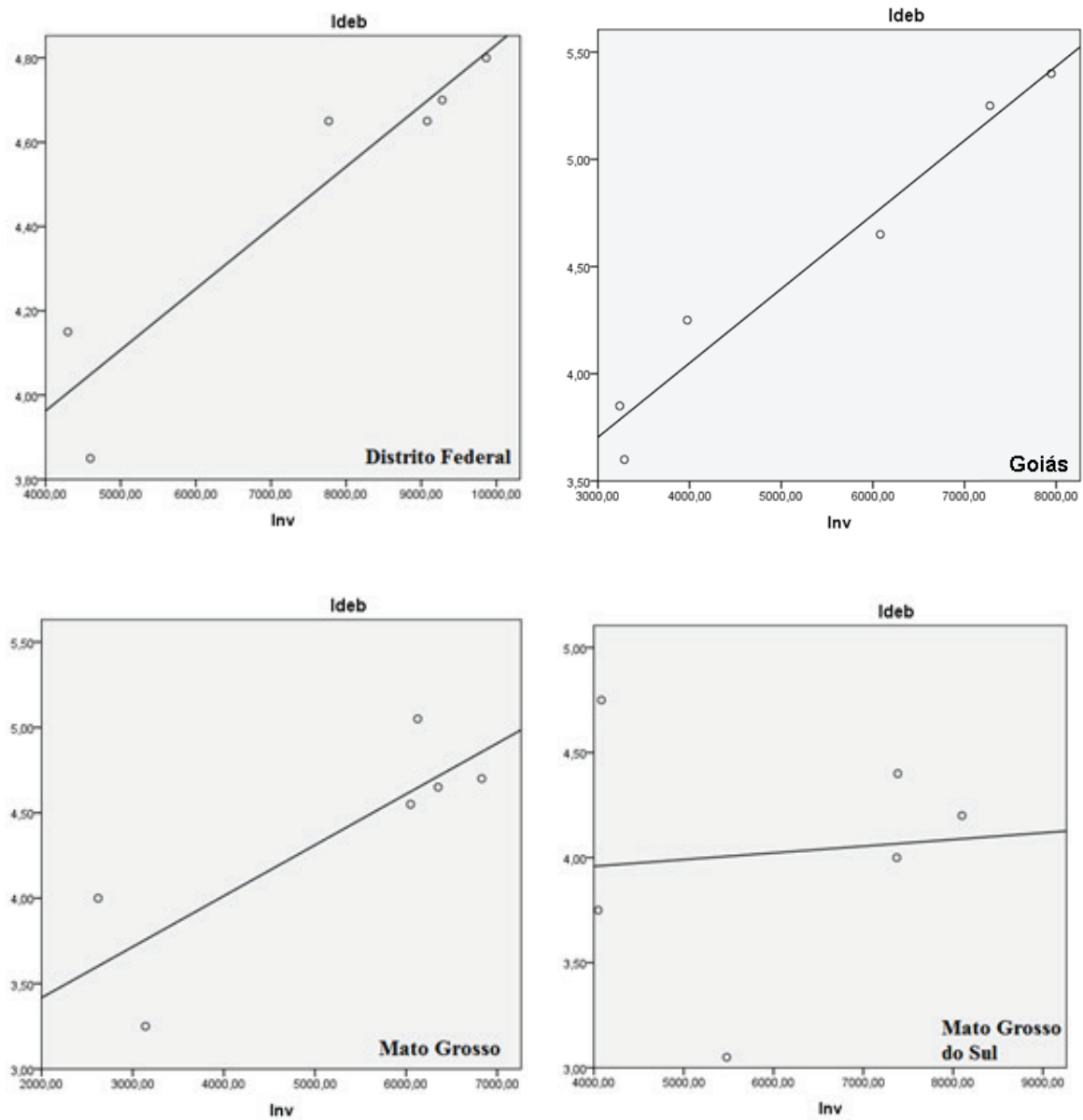

Source: Elaborated by the authors.

In the Midwestern region, there was a $70 \%$ growth in the amount invested per student in the period of analysis, increasing from $\mathrm{R} \$ 4,126.11$ to $\mathrm{R} \$ 7,005.60$, accompanied by growth of $45 \%$ in the Ideb average, which was 3.42 in 2005 and reached 4.60 in 2015. Regarding the capacity to explain the variables, the relation was strong for Goiás (R-square $=0.9598)$ and the Federal District (0.882), moderate for Mato Grosso $(0,70)$ and nonexistent for Mato Grosso do Sul $(0,009)$. The data suggest the state of Goiás invested the resources allocated to education better. Hence, the state with the closest relationship between investment and performance in the Midwest Brazilian region is Goiás. 
Figure 11 - Scatter graph for the Southeastern states.
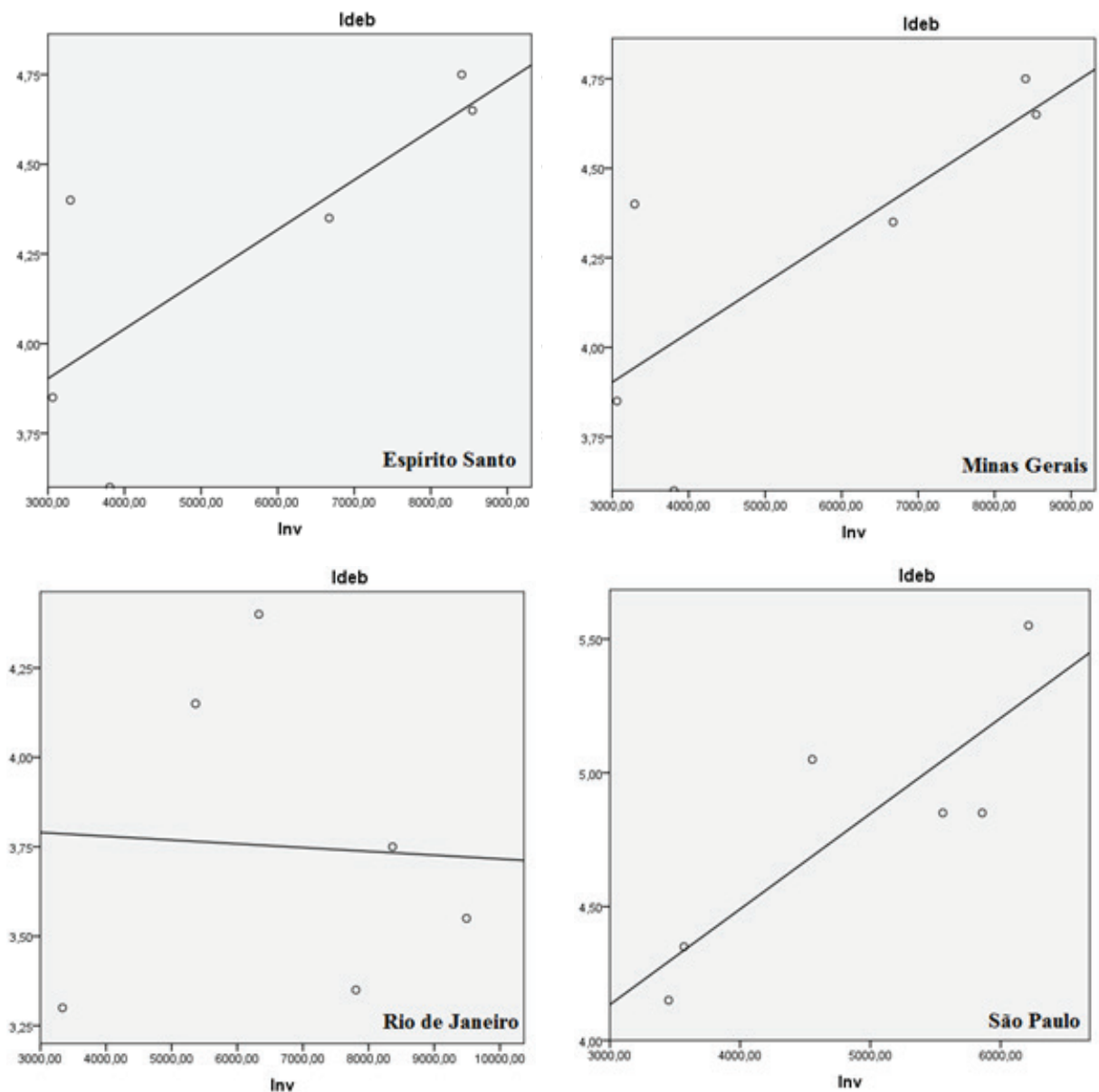

Source: Elaborated by the authors.

Likewise, in the Southeast region, the average increase in investment per student reached $119 \%$, rising from $R$ \$ 3,210.94 to $R$ \$ $7,038.33$. The growth in Ideb was, in turn, 31\%, going from 3.82 to 5.02. Regarding the explanatory capacity, it was practically perfect for Minas Gerais (R-square $=0.992)$, moderate for São Paulo (0.716) and Espírito Santo (0.61) and nonexistent for Rio de Janeiro (0.002). The best ratio being attributed to the state of Minas Gerais. 
Figure 12 - Scatter graph for the Southern states.
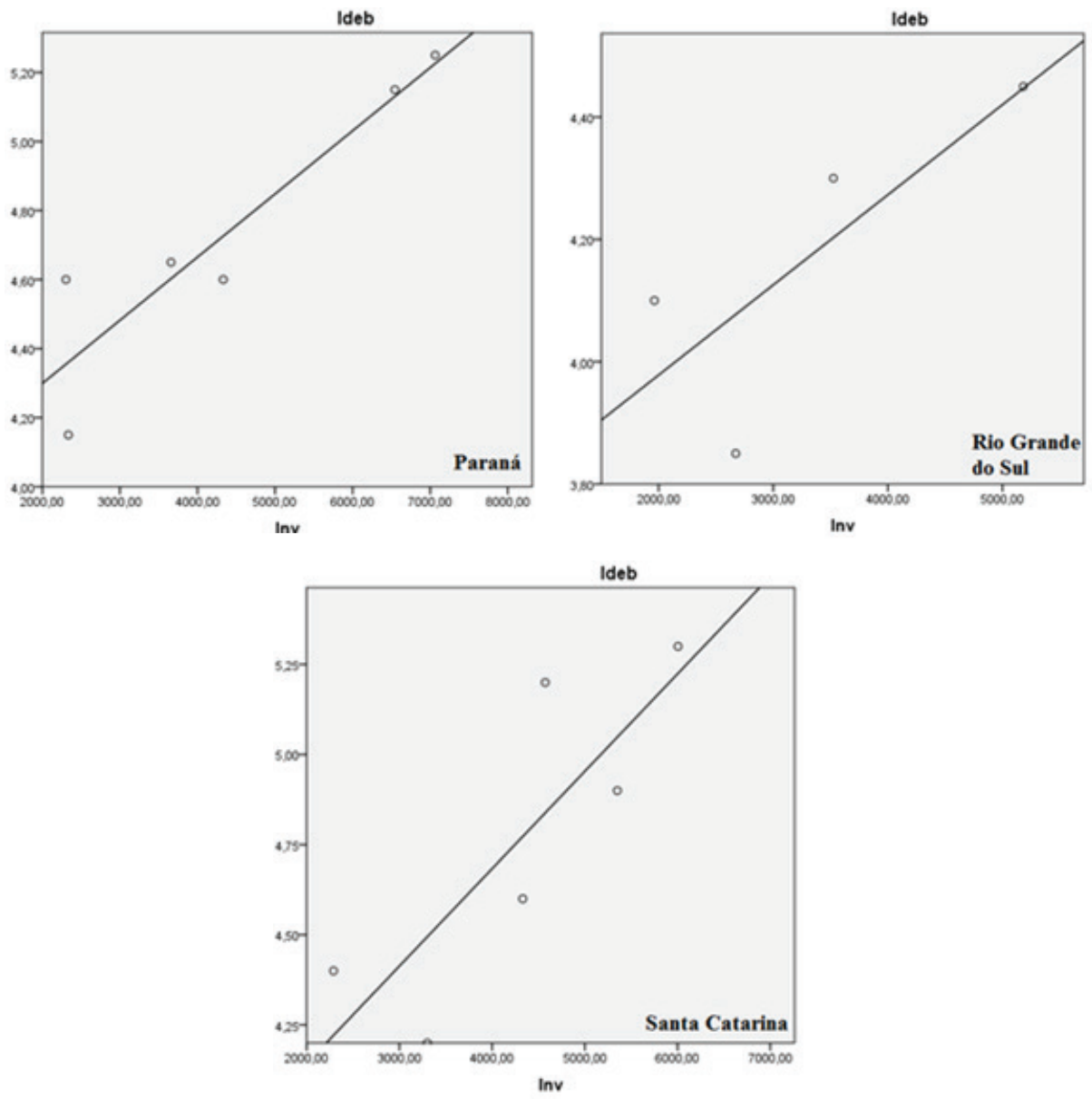

Source: Elaborated by the authors.

In the states of the Southern region, investment grew 119\%, from $\mathrm{R} \$ 2,769.32$ to $\mathrm{R} \$ 6,083.72$. The increase in Ideb, however, was only $25 \%$, going from 4.06 to 5.1 . Regarding the relationship between variables, it was strong for Paraná (0.85) and moderate for Santa Catarina (0.68) and Rio Grande do Sul (0.618). Paraná is the state with the highest correlation between the studied variables.

Finally, in the comparison by regions, the Midwest have raised investment per student less than the other regions and obtained the 
greatest variation in the Ideb. However, it should be remembered that each region made a distinct effort to improve the performance of its schools, based on performance values and investments peculiar to their conditions. Thus, due to the different levels of efficiency, even if data from those states with a high correlation at the individual level were used in the model, the points would still be highly dispersed.

\section{FINAL REMARKS}

By adopting the economic perspective of education, which assumes the quality of education can be determined through the effectiveness of the use of available resources, we sought to analyze the correlation between investment per student in the scope of elementary education, from 2005 to 2015 (from the beginning of the historical series to the last evaluation, which took place in 2015), and the results for student performance obtained in the national assessments. More specifically, the correlation between investment per student and the Index of Basic Education Development (Ideb) of each state as an indicator of student performance was examined. Linear regression was used in the research, since it enabled the analysis of the correlation between dependent and independent variables by constructing a linear model defined by a linear equation adjusted using the least-squares method (HAIR et al., 1998).

Accordingly, considering each state network as the starting point, it was found that in the Northern, Northeastern, Midwestern, Southeastern and Southern regions the networks with the best use of available resources were those of Roraima, Pernambuco, Goiás, Minas Gerais and Paraná, respectively. In general, it is found that when the ranking of best use of available resources, according to the established correlation, is constructed considering only the states, individually, Minas Gerais, Pernambuco and Goiás stand out, while Mato Grosso South, Piauí, Ceará and Rio de Janeiro states present no correlation between investments per student and performance in the Basic Education Development Index (Ideb).

This means the investments are necessary and can explain the improvement in the indices of learning, measured by the Ideb, up to a certain level. However, beyond that given point, investment no longer translates into improved learning outcomes, since Ideb results 
are no longer explained by the increase in investments per student. The results found in the Brazilian state public networks are similar to those reported by Hanushek $(2005,2012)$, that is, minimum levels of resources are necessary and valuable in promoting student learning, however, no consistent or systematic relationships was found to exist between student performance (measured by achievement in school performance assessment tests applied to universes of students from different schools, such as Brazil's national evaluations, like the Ideb) and investments per student.

Here, the results obtained using the statistical test show that the representativeness of the investment in the Ideb result was slightly more than $18 \%$. But what does this number represent? That, when correlating the variables, the coefficient of determination obtained was an R-square of 0.189 . This value indicates the predictive capacity of the tested model. Therefore, $18.9 \%$ of the variation in the Ideb scores can be explained by the variation in the investment per student in the period. And that, due to this association, we have a directly proportional force relationship between the variables, considering that the value assumed by $\mathrm{R}$ is greater than zero. That is, in relation to the performances obtained by the states in the Ideb, $18.9 \%$ is positively related to the variation in the resources invested per student in the period.

In other words, it means that, regarding a country the size of Brazil, there is a need to accompany the educational networks more closely, since they have very different learning outcomes, although the investments per student are quite similar. According to Hanushek and Wößmann (2007, p. 14), "unfortunately, simple and sophisticated analyzes yield the same answer: mere resource investment policies that adopt the already existing structure of school operations are not sufficient to lead to the necessary improvements in learning". That is, it is necessary to devote much more attention to the use of resources than to the amount invested.

On the other hand, the lack of a significant relationship for the states of Rio de Janeiro, Mato Grosso do Sul and Piauí may be associated with other factors that need to be better investigated in future research. In the data collection, for example, it was found that those states used, in the budget sheet, the item "other expenses with 
basic education", which does not separate the resources according to education modality. This factor may have been responsible for the absence of the studied relationship in these states and, at the same time, may indicate lack of transparency with the resources destined for education.

Attention is also drawn to those states whose investment per student was significantly low in 2005 and had Ideb scores between 3.0 and 4.0, and that, when they applied more resources for the maintenance and development of education, obtained a certain increase in terms of the national performance explained by the tested model. However, the same perspective was not observed when the states with the highest average spending, or those with the highest performance were analyzed. Therefore, it is suggested future research should analyze the networks individually and, even, compare schools with high and low performances that have received similar resources.

\section{REFERENCES}

ADELSBERGER, H. H.; KINSHUK, P.; PAWLOWSKI, J. M.; SAMPSON, D. (Ed.). Handbook on information technologies for education and training. Hardcover, 2008.

ALVES, M. T. G.; SOARES, J. F. As pesquisas sobre o efeito das escolas: contribuições metodológicas para a Sociologia da Educação. Sociedade e Estado, v. 22, n. 2, p. 435-73, 2007.

ALVES, M. T. G.; SOARES, J. F. Contexto escolar e indicadores educacionais: condições desiguais para a efetivação de uma política de avaliação educacional. Educação e Pesquisa, São Paulo, v. 39, n. 1, p. 177-94, 2013.

ARAÚJO, R. L. S. Desvendando o Perfil dos Gastos Educacionais dos Municípios Brasileiros. Educação e Sociedade, Campinas, v. 33, n. 121, p. 1215-33, 2012.

BAKER, B. D. Does Money Matter in Education? A Washington, DC: Albert Shanker Institute, 2016. BRASIL, Lei no 9.394. 1996. Disponível em: www.planalto.gov.br/ccivil_03/leis/L9394.htm . Acesso em: 18 jan. 2018.

BRASIL, Constituição Federal. 1998. Disponível em: www.planalto.gov.br/ccivil_03/constituicao/ constituicaocompilado.htm . Acesso em: 02 abr. 2019.

BRASIL, Lei n. 11.494. 2007. Disponível em www.planalto.gov.br/ccivil 03/ ato2007-2010/2007/ lei/111494.htm . Acesso em: 15 fev. 2019.

BRASIL, Decreto Federal n. 6.253. 2007. Disponível em: www.planalto.gov.br/ccivil_03/_ ato2007-2010/2007/decreto/d6253.htm . Acesso em: 18 jan. 2019.

BRASIL, Portaria MEC no 844. 2008. Disponível em: http://www.fnde.gov.br/fnde/legislacao/portarias/item/3564-portaria-mec-n\%C2\%BA-844-de-08-de-julho-de-2008 . Acesso em: 18 jan. 2019. 
BRASINGTON, D. M.; HAURIN, Donald R. Parents, peers, or school inputs: Which components of school outcomes are capitalized into house value? Regional Science and Urban Economics, v. 39, n. 5, p. 523-9, 2009.

BROOKE, N.; CUNHA, M. A. A avaliação externa como instrumento da gestão educacional nos estados. Estudos e Pesquisas Educacionais, São Paulo, v. 2, p. 17-79, 2011.

BROOKE, N.; SOARES, J. F. (Orgs.). Pesquisa em eficácia escolar: origem e trajetórias. Belo Horizonte: Editora UFMG, 2008.

CARD, D.; KRUEGER, A. B. School resources and student outcomes: an overview of the literature and new evidence from North and South Carolina. Journal of Economic Perspectives, v. 10, n. 4, p. 31-50, 1996.

CHILAND, C. L'enfant de 6 ans et som avenir. Paris: PUF, 1971.

COLEMAN, J.S.; CAMPBELL, E.Q.; HOBSON, C.J.; MCPARTLAND, J.; MOOD, A.M.; WEINFELD, F.D.; YORK, R.L. Equality of Educational Opportunity. Washington, US Government Printing Office, 1966.

DAVIES, N. A Fiscalização das Receitas e Despesas do Ensino em Minas Gerais. Cadernos de Pesquisa, São Paulo, v. 43, n.149, p. 518-54, 2013a.

DAVIES, N. Educação do Distrito Federal perdeu bilhões com erros do Tribunal de Contas. Linhas Críticas, Brasília, v. 19, n. 39, p. 355-72, 2013b.

DAVOK, D. F. Qualidade em educação. Avaliação, São Paulo, v. 12, n. 3, p. 505-13, 2007.

DEKE, J. A Study of the impact of public school spending on postsecondary educational attainment using statewide school district refinancing in Kansas. Economics of Education Review, v. 22, n. 3, p. 275-84, 2003.

DEMO, P. Ciências sociais e qualidade. São Paulo: ALMED, 1985.

DEMO, P. Educação e qualidade. São Paulo: Papirus, 2001.

FERNANDES, R.; GREMAUD, A. P. Qualidade da educação: avaliação, indicadores e metas. Educação básica no Brasil - construindo o país do futuro. Rio de Janeiro: Elsevier, v. 1, p. 213-38, 2009.

FIGLIO, D. Measuring school performance: Promise and pitfalls. In: Stiefel, L., Schwartz, A.E., Rubenstein, R., Zabel, J. (Eds.), Measuring School Performance and Efficiency: Implications for Practice and Research. Eye on Education, p. 119-36, 2004.

FIGLIO, D. Functional form and the estimated effects of school resources. Economics of Education Review, v. 18, n. 2, p. 24-52, 1999.

FIGLIO, D.; KENNY, L. Public sector performance measurement and stakeholder support. J. Public Econ. v. 93, n. 9, p. 1069-77, 2009.

FIGLIO, D.; KENNY, L. Individual teacher incentives and student performance. J. Public Econ. v. 91, n. 5, p. 901-14, 2007.

GUEDES, G. N. O.; BAQUEIRO, D. F. A.; LORDÊLLO, J. A. C. Equidade e eficácia escolar: histórico dos estudos. 2015. Disponível em: < http://www.equidade.faced.ufba.br/sites/ equidade.oe.faced.ufba.br/files/equidade_e_eficacia_escolar_-_historico_dos_estudos.pdf > 
HAIR, J.F., ANDERSON, R.E., TATHAM, R.L. and BLACK, W.C. Multivariate Data Analysis. Upper Saddle River, New Jersey: Prentice-Hall, 1998.

HANUSHEK, E. A. Education and the nation's future. In: SHULTZ, G. P. Blueprint for America. p. 89-108. Stanford, California: Hoover Institution Press Publication, 2016.

HANUSHEK, E. A. Economic growth in developing countries: The role of human capital. Economics of Education Review, 37, 204-12, 2013.

HANUSHEK, E. A. Education quality and economic growth. In: BRENDAN, M. The 4 percent solution: Unleashing the economic growth America needs. New York: Crown Business, p. 227-39, 2012.

HANUSHEK, E. A. Some US evidence on how the distribution of educational outcomes can be changed. In: WOESSMANN, L.; PETERSON, P. E. Schools and the equal opportunity problem. Cambridge: The MIT Press, p. 159-90, 2007.

HANUSHEK, E. A. Economic outcomes and school quality. International Academy of Education. International Institute for Educational Planning. Belgium/France: Stedi Média, 2005.

HANUSHEK, E. A. Making Schools Work: Improving Performance and Controlling Costs. Washington, D.C.: The Brookings Institution, 1994.

HANUSHEK, E. A. The impact of differential expenditures on school performance. Educational Researcher, v. 18, n. 4, p. 45-51, 1989.

HANUSHEK, E. A. The economics of schooling: production and efficiency in public schools. Journal of Economic Literature, v. 24, p. 1141-77, 1986.

HANUSHEK, E. A.; RIVKIN, S.G.; TAYLOR, L.L. Aggregation and the estimated effects of school resources. Review of Economics and Statistics, v. 78, n. 4, p. 611-27, 1996.

HANUSHEK, E. A.; WÖßMANN, L. Schooling, educational achievement, and the Latin American growth puzzle. Journal of Development Economics, v. 99, p. 497-512, 2012.

HANUSHEK, E. A.; WÖßMANN, L. Education and Economic Growth. In: PETERSON, P.; BAKER, E.; McGAW, B. (Eds), International Encyclopedia of Education. v. 2, p. 245-52. Oxford: Elsevier, 2010.

HANUSHEK, E. A.; WÖßMANN, L. Education Quality and Economic Growth. The International Bank for Reconstruction and Development/The World Bank. Washington DC, 2007.

HAURIN, D. R.; BRASINGTON, D. M. The impact of school quality on real house prices: Interjurisdictional effects, Journal of Housing Economics, v.5, n.4, 351-68. 1996.

HEDGES, L.; LAINE, R. D.; GREENWALD, R. Does money matter? A meta-analysis of the effects of differential schools inputs on student outcomes. Educational Researcher, v. 23, n. 3, p. 5-14, 1994.

HEDGES, L.; LAINE, R. D.; GREENWALD, R. The effect of school resources on student achievement. Review of Educational Research, v. 66, p. 361-96, 1996a.

HEDGES, L.; LAINE, R. D.; GREENWALD, R. Interpreting research on school resources and student achievement: a rejoinder to Hanushek. Review of Educational Research, v. 66, p. 411-16, $1996 \mathrm{~b}$. 
INSTITUTO NACIONAL DE ESTUDOS E PESQUISAS EDUCACIONAIS ANÍSIO TEIXEIRA (INEP). Avaliações da aprendizagem. 2011. Disponível em: http://portal.mec.gov.br/mais-educacao/190-secretarias-112877938/setec-1749372213/18843-avaliacoes-da-aprendizagem . Acesso em: 18 set. 2018.

INSTITUTO NACIONAL DE ESTUDOS E PESQUISAS EDUCACIONAIS ANÍSIO TEIXEIRA (INEP). Ideb. 2016. Disponível em: ideb.inep.gov.br. Acesso em: 18 set. 2018.

JENCKS, C. Inequality, a reassessment of the effect of family and schooling in America. New York: Basic Books, 1972.

KIM, H. Is there a crowding-out effect between school expenditure and mother's child care time? Economics of Education Review, v. 20, n. 1, p. 71-80, fev. 2001.

MENDONÇA NETO, O. R.; VIEIRA, A. M.; ANTUNES, M. T. P. Industrialização da educação, edtech e prática docente. Eccos, v. 3, n. 47, p. 149-170, 2018.

NASCIMENTO, P. A. M. School Resources and Student Achievement: Worldwide Findings and Methodological Issues. Educate - Especial Issue, p. 19-30, 2008.

NASCIMENTO, P. A. M. Recursos destinados à educação e desempenho escolar: uma revisão na literatura internacional. Estudos em Avaliação Educacional, v. 18, n. 36, 2007.

PAWLOWSKI, J. M. The quality adaptation model: adaptation and adoption of the Quality Standard ISO/IEC 19796-1 for Learning, Education, and Training. Summary, 2007.

PLOWDEN Report. Central Advisory Council for Education. Children and their primary schools. London: HMSO, 1967.

RIBEIRO, V.; GUSMÃO, J. B. B. de. Uma leitura dos usos dos indicadores da qualidade na educação. Cadernos de Pesquisa, v. 40, n. 141, p. 823-47, 2010.

SANDER, B. Administração da educação no Brasil: é hora da relevância. Educação Brasileira, Brasília, v. 4, n. 9, p. 8-27, 1982.

SANDER, B. Gestão da educação na América Latina: construção e reconstrução do conhecimento. Campinas, SP: Autores Associados, 1995.

SAVIANI, D. A nova lei da educação: trajetória, limites e perspectivas. Campinas: Autores Associados, 2001.

SCRIVEN, M. Evaluation thesaurus. Newbury Park, CA: Sage, 1991.

Sistema de Informações sobre Orçamentos Públicos em Educação (SIOPE). Relatórios estaduais. 2016. Disponível em: http://www.fnde.gov.br/fnde-sistemas/sistema-siope-apresentacao/ siope-relatorios-estaduais. Acesso em: 15 jan. 2019.

TAVARES JÚNIOR, F.; NEUBERT, L. F. A qualidade da educação e a disseminação de sistemas de avaliação. Estudos em Avaliação Educacional, São Paulo, v. 25, n. 59, p. 22-48, 2014.

VIEBRANTZ, R.; MOROSINI, M. C. Qualidade e educação superior: a norma de qualidade para a aprendizagem, educação e formação - ISO/IEC 19796-1. Educação, Porto Alegre, v. 32, n. 3, p. 277-285, 2009. 
WÖßMANN, L. Schooling resources, educational institutions, and student performance: the international evidence. Kiel Institute of World Economics, 2000.

WÖßMANN, L. Why Students in Some Countries Do Better. Education Matters, n. 1, v. 2, p. 67-74, 2001.

WÖßMANN, L. Schooling Resources, Educational Institutions, and Student Performance: The International Evidence. Oxford Bulletin of Economics and Statistics, v. 65, n. 2, p. 117-70, 2003.

WERLE, F. O. C.; KOETZ, C. M.; MARTINS, T. F. K. Escola pública e a utilização de indicadores educacionais. Educação, v. 38, n. 1, p. 99-112, 2015.

Recebido em: 15-8-2019

Aprovado em: 17-11-2020

Avaliado pelo sistema double blind review.

Disponível em http://mjs.metodista.br/index.php/roc 